\title{
Measuring in situ growth rates of an infaunal polychaete at different intertidal elevations
}

\author{
John A. Matthews, Brian T. Hentschel ${ }^{*}$ \\ Department of Biology \& Coastal and Marine Institute, San Diego State University, 5500 Campanile Drive, San Diego, \\ California 92182-4614, USA
}

\begin{abstract}
We developed methods to measure juvenile growth rates of the spionid polychaete Polydora cornuta in nature. We transplanted and recovered small vials containing labeled individuals and measured each worm's body volume before and after worms spent a week in field sediments. We transplanted labeled individuals to 3 elevations on an intertidal mudflat in Oneonta Slough within the Tijuana River National Estuarine Research Reserve: a high elevation $0.7 \mathrm{~m}$ above mean lower low water (MLLW), a mid-elevation $0.4 \mathrm{~m}$ above MLLW, and a low elevation $0.1 \mathrm{~m}$ above MLLW. To include a range of environmental conditions, we performed two $7 \mathrm{~d}$ transplantations in July 2009 and 2 in November 2009. On average, we recovered one-third of the transplanted juveniles. Mean relative growth rates (RGR) declined significantly from $7.7 \% \mathrm{~d}^{-1}$ at the low elevation to $2.4 \% \mathrm{~d}^{-1}$ at the high elevation. There was a positive correlation between RGR and the time each elevation was submerged, suggesting the decline in RGRs with increasing elevation was due to a reduction in the time available for suspension feeding. RGRs during 1 transplantation (12 to 19 November) were significantly slower than RGRs during the other 3 transplantations, especially at the high and mid elevations. Due to seasonality in the mixed semidiurnal tides, the 12 to 19 November period was the only transplantation that experienced lower low tides during the afternoon. The slower RGRs during this time of exposure to afternoon sunlight and air temperatures suggest physiological stress might have contributed to reduced RGRs during this transplantation.
\end{abstract}

KEY WORDS: Elevation - Intertidal $\cdot$ Vertical distribution $\cdot$ Growth rate $\cdot$ Polydora $\cdot$ Spionidae Suspension feeder $\cdot$ Salt marsh

\section{INTRODUCTION}

Within the intertidal, biological and physical factors work in concert to determine upper and lower limits of species' distributions. Studies of rocky-shore communities have emphasized the presence of intense vertical gradients and provided many central concepts in marine ecology (e.g. Connell 1972, Menge \& Sutherland 1976, Gaines \& Roughgarden 1985, Underwood 1985). In soft-sediment systems, vertical distribution patterns are apparent for a variety of animals (e.g. Kneib 1984, Peterson 1991, Dittmann 2000), but the biotic and abiotic mechanisms that cause these patterns are poorly understood compared to the rocky intertidal. The 3-dimen- sional nature of sediments and the mobility of many infauna make direct observation and manipulative experimentation more challenging in soft bottoms (Peterson 1991, Woodin 2007), especially when mechanistic questions pertain to the physiological performance of individual organisms in situ.

Growth is one of the most integrative measures of an individual's performance, particularly for nonreproductive juveniles. Measuring the growth rates of individuals in situ has been common in studies of hard-substrate communities (e.g. Connell 1972, Jarrett 2003, Phillips 2004). In soft-sediment systems, however, the few estimates that have been made of in situ growth rates of juvenile infauna are usually based on changes in the size-frequency distribution 
of a population, requiring fairly discrete recruitment of cohorts and an assumption that size-dependent mortality is not significant (e.g. Marsh \& Tenore 1990, Thompson \& Schaffner 2001). To address some of these methodological challenges, Qian \& Chia (1994) transplanted groups of stained siblings of Capitella sp. and measured the change in the mean size of the stained groups after $3 \mathrm{wk}$ in the field. Efforts to directly measure the in situ growth of individually labeled infauna have been limited to bivalves (e.g. Peterson \& Black 1987, 1988, Matthews \& Fairweather 2003, 2008).

In particular, Peterson \& Black $(1987,1988)$ transplanted individually labeled bivalves from 5 species and measured their growth and survival at 2 elevations on an intertidal mudflat to directly compare individual performance with species' patterns of vertical zonation. Changes in shell length were measured after several months (4 to 10 mo in Peterson \& Black 1987; 13.5 mo in Peterson \& Black 1988). Despite some species normally being most abundant in the high intertidal and others being restricted to the low intertidal, in general, all of the species grew more at the lower elevation, with some variability among sites and different experiments (Peterson \& Black 1987, 1988). In rocky intertidal systems, it is widely accepted that the necessary cessation of feeding during tidal exposure leads to decreased growth of suspension feeders at higher elevations (e.g. Barnes \& Powell 1953, Seed 1969, Suchanek 1978, Griffiths \& Buffenstein 1981). Peterson \& Black (1987, 1988) found the same general pattern for infaunal bivalves, but also noted that the magnitude of the reduction in growth at the higher elevation was 2 to $3 \times$ greater than the reduction in daily water coverage. Peterson \& Black $(1987,1988)$ suggested 2 possible explanations for the greater than expected decline in growth at the higher elevation: (1) additional physiological stress at the higher elevation or (2) a decline in the quality or quantity of suspended food at the higher elevation. Because suspensionfeeding bivalves living in high densities at low elevations might reduce the concentration of suspended food particles from the water before the rising tide supplies suspension feeders living at higher elevations, Peterson \& Black $(1987,1988)$ concluded that depletion of food during tidal inundation was the most likely explanation, and subsequent sampling of seston over the mudflat during a flooding tide has supported the food-depletion mechanism (Peterson \& Black 1991). Since these seminal experiments on infaunal bivalves, similar transplantation experiments have not been performed on other infaunal taxa.
Here, we report the transplantation and recovery of labeled individuals of a common intertidal spionid polychaete, Polydora cornuta, to directly measure their growth rates in situ. Although individual spionids are not labeled as easily as infaunal bivalves (e.g. by applying coded paint dots to their shells: Peterson \& Black 1987, 1988), P. cornuta and most other infaunal spionids reside in sediment tubes that are amenable to transplantation experiments. Their small size (often $<1 \mathrm{~cm}$ long) poses methodological challenges, but their rapid growth (e.g. Hentschel \& Larson 2005, 2006) facilitates transplantation experiments on a time scale of several days rather than several months. Spionids are common members of many soft-sediment communities, often achieving densities $>10000 \mathrm{~m}^{-2}$ (e.g. Zajac 1991a,b, Hentschel \& Larson 2006, Conlan et al. 2010). Their tube-building, feeding, and bioturbation activities alter the sediment and impact other members of the community (e.g. Thrush et al. 1996, Bolam \& Fernandes 2003). These worms are also important prey to higher trophic levels (Stehlik \& Meise 2000, Tomiyama et al. 2007) and are among the first colonists of disturbed sediments (e.g. Pearson \& Rosenberg 1978, Levin et al. 1996a). Most spionids are interface feeders (Dauer et al. 1981), having the ability to switch from deposit feeding to passive suspension feeding with increases in flow and the flux of suspended food particles (e.g. Taghon et al. 1980, Taghon \& Greene 1992, Bock \& Miller 1996). Laboratory flume experiments have revealed that the growth rates of juvenile $P$. cornuta are greatly enhanced when fluxes of suspended food favor suspension feeding (Hentschel 2004, Hentschel \& Larson 2005, 2006)

We adapted methods used in those laboratory flume experiments to measure the in situ growth rates of individual Polydora cornuta along a gradient of tidal elevation. Although spatial patterns in the abundances of infaunal polychaetes in intertidal sediments are commonly observed (e.g. Wilson 1983, Bolam \& Fernandes 2003, Larson et al. 2009), we are not aware of any previous in situ measurements of the growth or performance of infaunal polychaetes in relation to tidal elevation or other spatial features that vary on a small scale of meters.

\section{MATERIALS AND METHODS}

To measure variability in the growth rates of juvenile Polydora cornuta along an elevation gradient, we transplanted pre-measured individuals to 3 intertidal elevations on a mudflat and recovered and re- 
measured the labeled individuals $7 \mathrm{~d}$ after they were deployed to the field. The intertidal mudflat was located on the eastern bank of Oneonta Slough in the Tijuana River National Estuarine Research Reserve $\left(32.5648^{\circ} \mathrm{N}, 117.1313^{\circ} \mathrm{W}\right)$. The poorly sorted sediment has a mean grain size of $109 \mu \mathrm{m}(\mathrm{phi}=3.2)$ and is $45 \%$ silt $(<63 \mu \mathrm{m})$ by weight. We performed the transplantations on 2 dates in July and 2 dates in November of 2009 (Table 1). We planned 2 of the transplantations to include a new-moon spring tide (21 July and 16 November 2009) and 2 to include a neap tide (28 July and 9 November 2009). The site has mixed semidiurnal tides, with successive high and low tides usually differing in height (i.e. the extremes during a single day are referred to as 'lower low water' and 'higher high water').

Live Polydora cornuta were collected $2 \mathrm{~d}$ before each transplantation from a dense patch in Oneonta Slough $\sim 150 \mathrm{~m}$ north of the transplantation site by sieving 3 to $5 \mathrm{~cm}$ of surficial sediment in the field (0.5 mm mesh, Hentschel 2004). Worm tubes were then transported to the laboratory where they were sorted using a stereomicroscope. Individual $P$. cornuta were teased from their sediment tubes with forceps, and undamaged juveniles ranging in length from 2.0 to $6.5 \mathrm{~mm}$ were selected for the transplantations.

A total of 90 to 114 worms were used for each transplantation (Table 1). These worms were placed in a petri dish containing the vital stain Neutral Red ( $0.25 \mathrm{~g}$ dissolved in $1 \mathrm{l}$ of $1 \mu \mathrm{m}$ filtered seawater) for $15 \mathrm{~min}$. The staining ensured that worms we recovered from the field transplantations were the same pre-measured individuals rather than immigrants. Qian \& Chia (1994) reported that Polydora ligni (a synonym of P. cornuta: Blake \& Maciolek 1987) juveniles stained with Neutral Red grew to sexual maturity in laboratory culture at the same rate as unstained worms. In a pilot study conducted in a laboratory flume, we confirmed that $P$. cornuta juveniles stained with Neutral Red and unstained juveniles

Table 1. Polydora cornuta. Transplantation dates of pre-measured juvenile worms with recovery $7 \mathrm{~d}$ later. Numbers of individuals transplanted and recovered for each of the 3 intertidal elevations: High $=0.7 \mathrm{~m}$ above mean lower low water $(\mathrm{MLLW}), \mathrm{Mid}=0.4 \mathrm{~m}$ above MLLW, and Low $=0.1 \mathrm{~m}$ above MLLW

\begin{tabular}{|c|c|c|c|c|c|c|c|}
\hline \multirow[t]{2}{*}{$\begin{array}{l}\text { Transplan- } \\
\text { tation date }\end{array}$} & \multirow[t]{2}{*}{$\begin{array}{l}\text { Recovery } \\
\text { date }\end{array}$} & \multicolumn{3}{|c|}{$\begin{array}{c}\text { No. worms } \\
\text { transplanted }\end{array}$} & \multicolumn{3}{|c|}{$\begin{array}{c}\text { No. worms } \\
\text { recovered }\end{array}$} \\
\hline & & High & Mid & Low & High & Mid & Low \\
\hline 16 Jul 2009 & 23 Jul 2009 & 30 & 30 & 30 & 12 & 13 & 17 \\
\hline 23 Jul 2009 & 30 Jul 2009 & 38 & 38 & 38 & 21 & 7 & 5 \\
\hline 5 Nov 2009 & 12 Nov 2009 & 30 & 30 & 30 & 10 & 13 & 6 \\
\hline 12 Nov 2009 & 19 Nov 2009 & 30 & 30 & 30 & 5 & 5 & 9 \\
\hline
\end{tabular}

both had indistinguishable mean relative growth rates of $0.08 \mathrm{~d}^{-1}$ (Colvin \& Hentschel unpubl. data). After staining, worms were anesthetized in $5 \% \mathrm{MgCl}$ and photographed individually with a Sony HDRHC7 camcorder connected to a Leica MZ 12.5 stereomicroscope and a Macintosh computer with I-Movie software. Using ImageJ software, we measured the body length of each individual and its width at 5 locations to calculate its body volume as the sum of 4 conical frustums (Hentschel 2004). The volume of each frustum was calculated as:

$V=(\pi / 3) \times L \times\left[\left(W_{1} / 2\right)^{2}+\left(W_{1} / 2\right)\left(W_{2} / 2\right)+\left(W_{2} / 2\right)^{2}\right]$

where $V$ is the volume of the frustum, $L$ is the length of the frustum, and $W_{1}$ and $W_{2}$ are the 2 width measurements at each end of the frustum.

Each measured worm was then transferred to filtered seawater for $15 \mathrm{~min}$ and then placed in an individually numbered vial containing defaunated sediment. Field-collected sediment was defaunated by freezing, thawing, sieving to remove particles larger than $0.3 \mathrm{~mm}$, freezing a second time, and then thawing again prior to use with worms. The vials containing pre-measured, stained individuals consisted of 2 concentric cylinders (both $2 \mathrm{~cm}$ high) made from $2 \mathrm{~mm}$ thick polypropylene tubing and sealed at the bottom with Hot Melt Glue. After filling a vial with defaunated sediment, a pre-measured worm was placed into the central cylinder (5 $\mathrm{mm}$ inner diameter). The outer cylinder (16 mm outer diameter) ensured that the worm was located near the center of the entire vial and aided in the recovery of transplanted worms. The numbered vials were placed in a $1.3 \mathrm{~cm}$ thick PVC slab $(30 \times 15 \mathrm{~cm})$ with $16.7 \mathrm{~mm}$ holes drilled to secure the vials. Each slab held 10 to 13 worm vials located randomly, and each of the 4 transplantation periods included a total of 9 PVC slabs. PVC slabs were then placed in a seawater table $\left(15^{\circ} \mathrm{C}, 30 \%\right.$ salinity $)$ to allow worms to build sediment tubes and acclimate to the vials for 12 to $15 \mathrm{~h}$ before being transported to the field. To transport worm vials, each PVC slab was placed in a covered plastic box $(33 \times 20 \mathrm{~cm})$ filled with a thin film of filtered seawater to prevent desiccation and erosion of sediment.

PVC slabs containing worm vials were transplanted into the mudflat in 3 parallel transects that were perpendicular to the tidal channel and separated by $1 \mathrm{~m}$. Stakes marked the ends of each transect, and a string connecting the stakes was used to measure the exact locations of the transplanted 
worm vials. Transplantations occurred at 3 elevations: a high intertidal elevation $0.7 \mathrm{~m}$ above mean lower low water (MLLW), a mid-intertidal elevation $0.4 \mathrm{~m}$ above MLLW, and a low intertidal elevation $0.1 \mathrm{~m}$ above MLLW. The high intertidal site was separated from vegetation on the bank of the channel by $3 \mathrm{~m}$ horizontally, and the low intertidal site was $\sim 5 \mathrm{~m}$ horizontally from the center of the tidal channel at MLLW.

During pilot studies, we determined that burying the vials so their top edges were flush with the sediment-water interface was critical to the successful recovery of transplanted worms. If the top edges of vials were buried $>2 \mathrm{~mm}$ below the sediment-water interface, worms could extend their sediment tubes horizontally beyond the confines of the vial. If vials were exposed above the sediment-water interface, erosion of the vials' contents was common. To facilitate accurate burial of the worm vials, we first buried a Plexiglas tray $(48 \times 31 \mathrm{~cm}$ with side walls $2 \mathrm{~cm}$ high, the same height as the vials) at each elevation along each of the 3 transects $2 \mathrm{~d}$ before each transplantation. Having these trays buried in situ for $2 \mathrm{~d}$ before burying the PVC slabs containing worm vials made it easier to accurately bury the vials flush with the sediment-water interface. We removed sediment from the center $(\sim 32 \times 17 \mathrm{~cm})$ of each pre-buried Plexiglas tray and inserted a PVC slab containing vials of premeasured worms. Nearby sediment was added, and the entire area encompassing the Plexiglas tray was smoothed with a straight edge so that the top edges of the vials and the Plexiglas tray appeared flush with the sediment-water interface. Because pilot studies revealed that we were unlikely to recover at least half of the transplanted worms, we decided a priori to pool all data from the 3 transects rather than potentially testing for differences among transects; the transects simply provided a means to relocate the 3 PVC slabs buried at each elevation.

PVC slabs and vials were recovered and transported to the laboratory in plastic boxes $7 \mathrm{~d}$ after each transplantation was initiated. Individual vials were then rinsed with a stream of filtered seawater to expose worms' U-shaped sediment tubes, which were often attached to the inner edge of the vial's central cylinder. Worm tubes were then gently removed from the vials with forceps, and worms were teased from their tubes and re-measured to calculate each individual's final body volume. Relative growth rates (RGR) were calculated assuming exponential rates according to Fisher (1921) as:

$$
\mathrm{RGR}=\left[\ln \left(V_{\mathrm{f}}\right)-\ln \left(V_{\mathrm{i}}\right)\right] / t
$$

where $V_{\mathrm{f}}$ and $V_{\mathrm{i}}$ are measurements of each individual's final and initial body volume, respectively (Hentschel 2004), and $t$ is time.

Environmental data during the 4 transplantation periods were acquired from data loggers operated by the National Oceanic and Atmospheric Administration (NOAA) National Estuarine Research Reserve Network (NOAA 2004). Data on water depth, water temperature, turbidity, dissolved oxygen, and salinity were obtained from the Oneonta Slough water station $\left(32.56830^{\circ} \mathrm{N}, 117.13127^{\circ} \mathrm{W}\right.$; YSI 6600 Multi-Parameter Environmental Monitoring System) $~ 300 \mathrm{~m}$ north of our transplantation site. Air temperatures were obtained from the Tidal Linkage weather station $\left(32.57461^{\circ} \mathrm{N}, 117.12701^{\circ} \mathrm{W}\right.$; Campbell Scientific Meteorological Station CR1000) 1 km northeast of our transplantation site. Data is recorded by the instruments every $5 \mathrm{~s}$ and averaged in $15 \mathrm{~min}$ intervals. In particular, we used the measured water depths to calculate the amount of time that each tidal elevation was submerged each day.

A 2-way ANOVA was applied to test the effects of tidal elevation and transplantation date on the RGR of Polydora cornuta. Post hoc Tukey's HSD comparisons identified significant differences among means. A linear regression was also applied to show the relationship between RGR and the average amount of time each elevation was submerged each day.

\section{RESULTS}

On average, we recovered one-third of the transplanted worms (Table 1). The proportion of worms recovered did not vary significantly among the 3 tidal elevations $\left(F_{2,9}=0.178, \mathrm{p}=0.839\right)$ or among the 4 transplantation periods $\left(F_{3,8}=1.713, \mathrm{p}=0.241\right)$. In a few additional cases, a worm was damaged during removal from its vial; these damaged worms were not re-measured and not included in the analyses. Although our recovered vials collected many meioand macrobenthos in the field and occasionally collected a Polydora cornuta recruit $<1.5 \mathrm{~mm}$ long, we never found $P$. cornuta individuals in our vials that might be confused with the pre-measured, stained individual (i.e. the staining was helpful, but not essential).

The 4 transplantations consistently showed that the RGR of juvenile Polydora cornuta varied significantly among the 3 tidal elevations (Fig. $1 ; F_{2,111}=16.262$, $\mathrm{p}<0.001)$. Tukey's test showed that the mean RGR at the low intertidal elevation was significantly slower than those at the 2 higher elevations ( $p<0.001)$; 


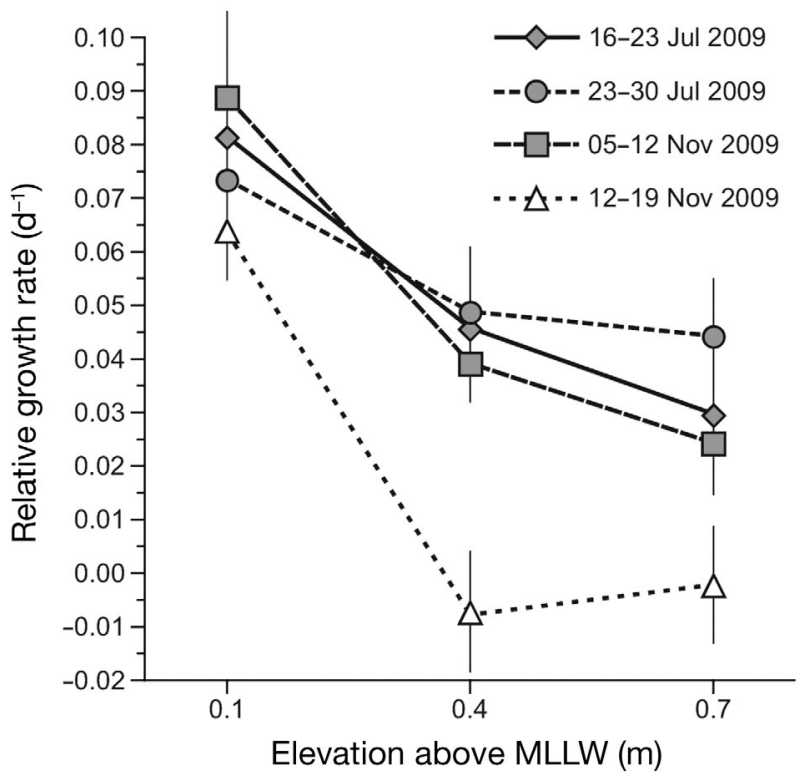

Fig. 1. Polydora cornuta. Mean $( \pm \mathrm{SE})$ relative growth rates (RGR) of juvenile worms at 3 elevations above mean lower low water (MLLW) during the 4 transplantation periods. Lines connect mean RGRs from the same $7 \mathrm{~d}$ transplantations. Sample sizes associated with each mean RGR are reported in Table 1 as number of worms recovered

RGRs at the mid- and high intertidal elevations did not differ from each other significantly $(p=0.685)$. The RGRs also differed significantly among the 4 transplantation periods $\left(F_{3,111}=3.994, \mathrm{p}=0.011\right)$. Tukey's test revealed that the mean RGR during the 12 to 19 November 2009 transplantation was significantly slower than the mean RGRs during the other 3 transplantations $(\mathrm{p}<0.035)$. Overall, there was not a significant interaction between the effects of elevation and transplantation date $\left(F_{6,111}=0.668, \mathrm{p}=\right.$ 0.742). In addition, there was not a significant relationship between mean RGR and the proportion of worms recovered $\left(F_{1,10}=0.432, \mathrm{p}=0.526\right)$.

Environmental data were collected during each transplantation period to aid in the interpretation of the RGR data (Table 2). The most noteworthy parameter is the time of day when lower low water (LLW) occurred (Table 2). Due to the seasonal change in the timing of LLW, the 12 to 19 November 2009 transplantation period was the only one of the 4 periods that had LLW during the afternoon (Table 2). This resulted in the mudflat being exposed to direct sunlight and the warmest air temperatures of each day more often during this transplantation than during the other 3 transplantations. Tidal range varied as planned, with the 2 periods that included a spring tide (16 to 23 July and 12 to 19 November 2009) having a greater mean tidal range than the 2 periods that included a neap tide (23 to 30 July and 5 to 12 November 2009). Due to seasonality in the mixed-semidiurnal tidal cycle, neither the 2 spring tides nor the 2 neap tides were identical (Tables $2 \& 3$ ). In particular, the elevation of higher high water (HHW) during the spring tide on 21 July was $1.60 \mathrm{~m}$ above MLLW, while the HHW elevation during the spring tide on 16 November was $1.30 \mathrm{~m}$ above MLLW. This difference in HHW during the 2 spring-tide periods resulted in slightly greater submergence time at the high and mid-intertidal elevations during the 16 to 23 July transplantation compared to the 12 to 19 November transplantation (Table 3). Water and air

Table 3. Mean $( \pm \mathrm{SE})$ time each elevation was submerged each day. High $=0.7 \mathrm{~m}$ above mean lower low water $(\mathrm{MLLW}), \mathrm{Mid}=0.4 \mathrm{~m}$ above MLLW, Low $=0.1 \mathrm{~m}$ above MLLW

\begin{tabular}{|c|c|c|c|}
\hline \multirow[t]{2}{*}{$\begin{array}{l}\text { Transplantation } \\
\text { period }\end{array}$} & \multicolumn{3}{|c|}{$\begin{array}{l}\text { Time each elevation was submerged } \\
\qquad\left(\mathrm{h} \mathrm{d}^{-1}\right)\end{array}$} \\
\hline & High & Mid & Low \\
\hline 16-23 Jul 2009 & $9.7 \pm 0.6$ & $15.4 \pm 1.0$ & $20.7 \pm 0.5$ \\
\hline 23-30 Jul 2009 & $8.6 \pm 0.8$ & $17.0 \pm 1.1$ & $20.9 \pm 0.6$ \\
\hline 5-12 Nov 2009 & $10.0 \pm 0.8$ & $16.9 \pm 0.6$ & $22.3 \pm 0.4$ \\
\hline 12-19 Nov 2009 & $8.4 \pm 0.6$ & $13.9 \pm 1.1$ & $21.4 \pm 0.3$ \\
\hline
\end{tabular}

Table 2. Environmental data collected by data loggers during each transplantation period. Time of lower low water (LLW) is reported for the daily LLW nearest the midpoint of each $7 \mathrm{~d}$ transplantation period. Tidal range, maximum and minimum air temperature values are mean \pm SE of 7 daily measurements during each transplantation period. Water temperature, turbidity (NTU: nephelometer turbidity units), dissolved oxygen, and salinity values are mean \pm SE of measurements collected every 15 min

\begin{tabular}{|lcccccccc|}
\hline $\begin{array}{l}\text { Transplan- } \\
\text { tation period }\end{array}$ & $\begin{array}{c}\text { Time of } \\
\text { LLW }\end{array}$ & $\begin{array}{c}\text { Tidal range } \\
(\mathrm{m})\end{array}$ & $\begin{array}{c}\text { Max. air } \\
\text { temperature } \\
\left({ }^{\circ} \mathrm{C}\right)\end{array}$ & $\begin{array}{c}\text { Min. air } \\
\text { temperature } \\
\left({ }^{\circ} \mathrm{C}\right)\end{array}$ & $\begin{array}{c}\text { Water } \\
\text { temperature } \\
\left({ }^{\circ} \mathrm{C}\right)\end{array}$ & $\begin{array}{c}\text { Turbidity } \\
(\mathrm{NTU})\end{array}$ & $\begin{array}{c}\text { Dissolved } \\
\text { oxygen } \\
\left.(\mathrm{mg} \mathrm{l})^{-1}\right)\end{array}$ & $\begin{array}{c}\text { Salinity } \\
(\%)\end{array}$ \\
\hline 16-23 Jul 2009 & $02: 45$ & $1.6 \pm 0.08$ & $24.0 \pm 0.26$ & $17.8 \pm 0.28$ & $22.1 \pm 0.08$ & $4.5 \pm 0.08$ & $4.1 \pm 0.10$ & $34.4 \pm 0.04$ \\
23-30 Jul 2009 & $07: 00$ & $1.1 \pm 0.07$ & $23.7 \pm 0.23$ & $18.4 \pm 0.18$ & $23.4 \pm 0.08$ & $5.7 \pm 0.10$ & $3.8 \pm 0.10$ & $35.0 \pm 0.04$ \\
5-12 Nov 2009 & $21: 45$ & $1.2 \pm 0.07$ & $19.7 \pm 0.97$ & $11.9 \pm 0.52$ & $16.7 \pm 0.04$ & $3.4 \pm 0.05$ & $5.8 \pm 0.05$ & $34.2 \pm 0.01$ \\
12-19 Nov 2009 & $15: 30$ & $1.5 \pm 0.05$ & $19.0 \pm 0.31$ & $10.2 \pm 0.77$ & $16.2 \pm 0.04$ & $3.3 \pm 0.06$ & $6.5 \pm 0.05$ & $34.1 \pm 0.02$ \\
\hline
\end{tabular}


temperatures were greater during the 2 July transplantations than during the 2 November transplantations, and the temperature values during the 2 transplantations within each month were very similar to each other (Table 2). Dissolved oxygen in the tidal channel was lower in July than in November, but values were always $>3.5 \mathrm{mg} \mathrm{l}^{-1}$ (Table 2). Turbidity was greater in July than in November (Table 2). Salinity was fairly constant, which is not surprising because it did not rain during or shortly before any of the transplantation periods (Table 2).

There was a significant linear relationship between RGR and mean daily submergence time $\left(F_{1,10}=\right.$ $16.109, \mathrm{p}=0.002, \mathrm{r}^{2}=0.617$ ). Because the 12 to 19 November 2009 transplantation was unique in experiencing afternoon LLW, we also performed the regression on a subset of the data that excluded the 12 to 19 November 2009 transplantation (Fig. 2). The relationship between RGR and submergence times remained significant, but had a lesser slope and a higher $\mathrm{r}^{2}$ than the regression that included all 4 transplantations (Fig. 2) $\left(F_{1,7}=21.165, \mathrm{p}=0.002, \mathrm{r}^{2}=0.751\right)$.

To quantify the proportional decline in RGR with decreasing submergence time, we calculated the proportional RGR as the mean RGR at each elevation divided by the mean RGR at the low elevation during the same transplantation period (i.e. the proportional RGR at the low elevation $=1.0$ for each of the 4 trans- plantations). Similarly, we calculated the proportional submergence time as the mean daily submergence time at each elevation divided by the mean submergence time at the low elevation during the same transplantation period. If the amount of time worms are submerged is paramount to their growth, the relationship between proportional RGR and proportional submergence time should be a line with a slope of 1 (Fig. 3). Because all of the data from the low elevation are set to a proportional RGR $=1.0$ and a proportional submergence time $=1.0$, statistical analyses will be overly weighted if all of these identical, fixed points are included. Therefore, we took a conservative approach and excluded all but one of the values from the low elevation when performing least-squares regression analyses of proportional RGR versus proportional submergence time. When all 4 transplantations were included in the regression, the relationship was not significant at $\alpha=0.05\left(F_{1,7}=4.616, \mathrm{p}=0.069, \mathrm{r}^{2}=\right.$ 0.397). When data from the 12 to 19 November 2009 transplantation were excluded because this transplantation was unique in having afternoon low tides, the linear relationship between proportional RGR and proportional submergence time during the remaining 3 transplantations was significant with a slope of 0.813 (Fig. 3, $F_{1,5}=6.681, \mathrm{p}=0.049, \mathrm{r}^{2}=$ 0.572 ). This slope of 0.813 was not significantly different from a slope of $1(t=0.596, \mathrm{df}=5, \mathrm{p}=0.577)$.

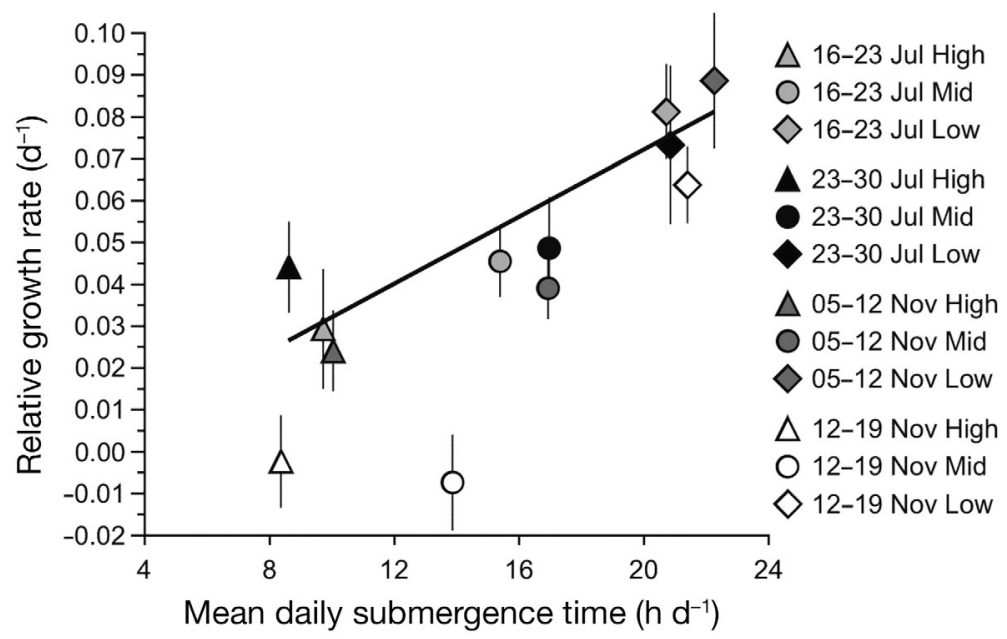

Fig. 2. Polydora cornuta. Mean $( \pm \mathrm{SE})$ relative growth rates (RGR) of worms versus mean daily submergence time at each elevation during each $7 \mathrm{~d}$ transplantation. Symbol shading: 4 transplantation periods; Intertidal elevations: High (triangle) $=0.7 \mathrm{~m}$ above mean lower low water $($ MLLW), Mid $($ circle $)=0.4 \mathrm{~m}$ above MLLW, and Low (rhombus) $=0.1 \mathrm{~m}$ above MLLW. Plotted regression line $\left(y=0.004 x-0.008 ; F_{1,7}=21.165, \mathrm{p}=\right.$ $0.002, \mathrm{r}^{2}=0.751$ ) was calculated based on the 9 mean RGRs from the first 3 transplantations (i.e. 12 to 19 Nov 2009 data plotted here but excluded from this regression)

\section{DISCUSSION}

Our measurements of the RGR of juvenile Polydora cornuta at 3 intertidal elevations during 4 week-long periods in Oneonta Slough are among the first direct measurements of the growth of individual infaunal polychaetes in situ. Although we typically recovered only one-third of the transplanted individuals, directly measuring the change in size of each individually labeled worm that was recovered reduces potential biases and uncertainties inherent in approaches that transplant a group that has a mean size measured at the start of the transplantation and a subset that has a larger mean size after recovery. In the latter approach, the increase in size could result from either growth or a loss of small individuals from the group during the transplantation period. Labeling individuals provides direct confirmation that the 


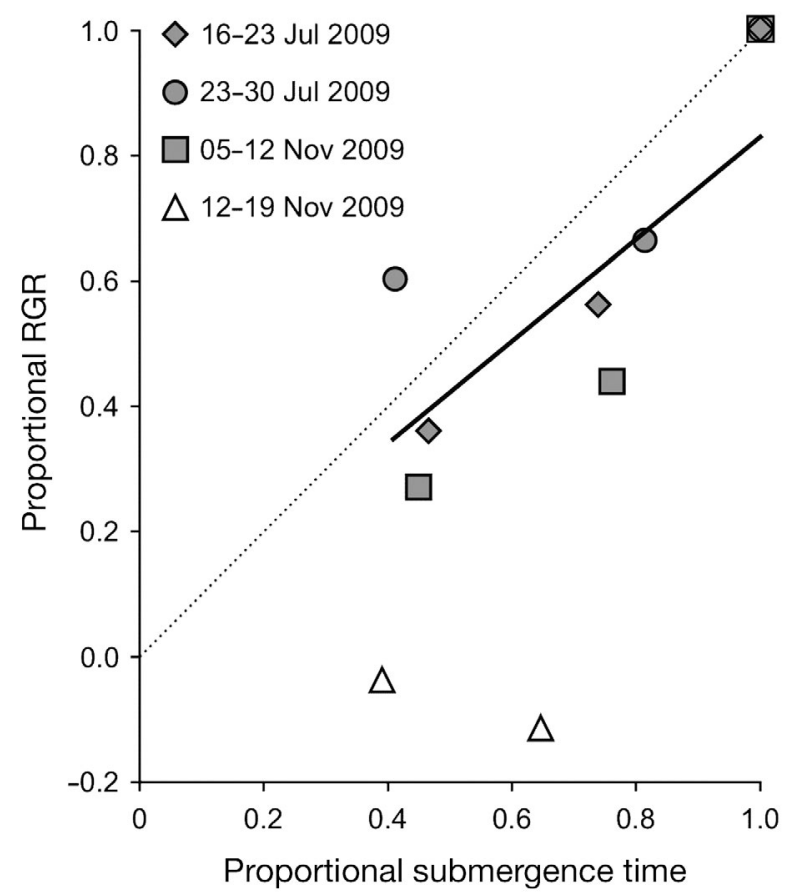

Fig. 3. Polydora cornuta. Proportional relative growth rates (RGR) of worms versus proportional submergence time. Proportional RGR: mean RGR at each elevation divided by mean RGR at the low elevation during the same transplantation period (i.e. the proportional RGR at the low elevation $=1.0$ for each of the 4 transplantations). Proportional submergence time: mean daily submergence time at each elevation divided by mean daily submergence time at the low elevation during the same transplantation period. Dotted line: 1:1 ratio between proportional RGR and proportional submergence time. Black line: least-squares regression $(y=0.813 x+$ $0.017 ; F_{1,5}=6.681, \mathrm{p}=0.049, \mathrm{r}^{2}=0.572$ ) calculated from the first 3 transplantations with only 1 of 3 identical data points from the low elevation included in the regression analysis. Data from 12 to 19 Nov 2009 are plotted, but excluded from the regression

recovered worms actually grew during their $7 \mathrm{~d}$ transplantation period.

When extrapolating the directly measured RGRs of recovered individuals to a broader population, one must assume the probability of any individual being recovered is random. Recovering a minority of the transplanted individuals can raise questions about the reasons individuals are not recovered and whether recovery is random or biased in some way. Several lines of evidence suggest an assumption of random recovery is reasonable. First, the proportion of worms recovered did not vary significantly with either tidal elevation or transplantation date, indicating that measured differences in RGR among elevations and dates cannot be explained simply by differences in recovery. Second, the small size of juvenile
Polydora cornuta poses obvious methodological challenges when transplanting individuals to the field. In particular, we suspect mechanical disturbances during transport to and from our field site probably caused some worms to leave their tubes. Third, adult $P$. cornuta have been shown to emigrate from their tubes in a laboratory flume experiment (Stocks 2002), but we are not aware of any studies demonstrating that an individual's growth rate or other measures of its physiological condition influence whether a juvenile remains in its tube or vacates it. Similarly, P. cornuta are documented prey (Stehlik \& Meise 2000, Tomiyama et al. 2007), but there are no data indicating a relationship between the physiological condition of $P$. cornuta and susceptibility to predation. In fact, we caution against strictly interpreting our recovery proportions as estimates of mortality, which can be measured with fewer artifacts by monitoring the abundance of natural populations. Although the exact reasons why many transplanted worms are not recovered cannot be known, available evidence does not suggest that extrapolating the RGRs of recovered individuals to a broader population is likely to be influenced by potentially biased, nonrandom recovery.

Results from the 4 transplantations at 3 elevations on a single mudflat show that the RGRs of juvenile Polydora cornuta declined with increasing tidal elevation at this site. We suspect the reduced growth rates at higher elevations resulted primarily from reduced time worms are able to feed. In particular, suspension feeding is only possible when the substrate is submerged, and slower growth of suspension-feeding invertebrates is well documented as intertidal elevation increases and the time available for suspension feeding decreases (e.g. Seed 1969, Griffiths \& Buffenstein 1981, van Erkom Schurink \& Griffiths 1993, Bishop \& Peterson 2006). Although $P$. cornuta and similar spionids can facultatively switch to deposit feeding (Taghon et al. 1980, Dauer et al. 1981), conditions that promote suspension feeding greatly increase juvenile growth rates in laboratory flume experiments (Hentschel 2004, Hentschel \& Larson 2005, Hentschel \& Herrick 2005). Although $P$. cornuta might be able to deposit feed if a thin film of water or shallow pool persists after tidal coverage recedes, this opportunity for deposit feeding at times when suspension feeding is not possible will only last briefly as the exposed sediment surface dries. Furthermore, nutritious particles within the worms' deposit-feeding area will be depleted quickly and not resupplied until the flooding tide (Miller et al. 1984, Miller \& Jumars 1986, Bock \& Miller 1995). 
In addition to the overall decline in RGR with increasing elevation, we also found significantly slower growth during the 12 to 19 November 2009 transplantation, especially at the mid- and high intertidal elevations. The fact that this transplantation period was the only one of the 4 that experienced LLW during the afternoon suggests increased physiological stress during the 12 to 19 November 2009 transplantation relative to the other 3 transplantations. This mudflat on the eastern bank of Oneonta Slough has a west-facing slope and receives several hours of direct sunlight when LLW occurs during mid afternoon. Variations in other measured environmental parameters alone (Table 2) do not correspond to the pattern of differences in RGR among the 4 transplantations. For example, if water temperature, air temperature, turbidity, or dissolved oxygen had a strong effect on RGR, we would expect similar RGRs during the two November transplantations and clear differences between the RGRs in July and those in November, which did not occur. We caution that unmeasured variables might have contributed to slower growth during the 12 to 19 November transplantation, but the distinct timing of LLW provides the most parsimonious explanation based on available data. This hypothesis about the mechanism that might have caused slower growth during the 12 to 19 November 2009 transplantation can be tested by future field experiments that replicate transplantations with afternoon LLW and/or manipulate direct sunlight and air temperature by shading portions of the mudflat. For example, Wethey (1984) showed that shading increased the survival of barnacles in the rocky intertidal.

Analysis of the 3 transplantations that experienced LLW during the night or early morning shows that RGR appeared to decline in direct proportion to the decline in submergence time. The slope near 1 suggests that the time available for feeding, especially suspension feeding, is the main determinant of worms' growth along the elevation gradient at this site. Peterson \& Black $(1987,1988)$ compared the growth of infaunal bivalves at 2 elevations and found a proportionally greater decline in growth than could be explained solely by submergence time. Rather than implicating additional physiological stress at higher elevations, they concluded that bivalves feeding at lower elevations depleted food particles available for suspension feeders living at higher elevations. The slower RGRs of Polydora cornuta juveniles during the 12 to 19 November transplantation and the deviation from the 1:1 relationship between proportional RGR and proportional submergence time evident in the other 3 transplantations are most likely explained by additional physiological stress at the mid- and high intertidal elevations during this transplantation period. Although we did not measure the density of bivalves or other active suspension feeders that might be capable of significantly depleting nutritious seston at lower elevations, it is unlikely that the densities of active suspension feeders effectively differed between the 5 to 12 and 12 to 19 November 2009 transplantations. The alternative hypotheses of increased physiological stress during afternoon low tides and exploitative competition among suspension feeders along an elevation gradient could be tested by transplanting spionids to highintertidal locations that had different densities of lower-intertidal bivalves.

Our successful transplantation and recovery of small and rapidly growing opportunistic infauna provides many opportunities for ecologists to directly test hypotheses about variability in the performance of individual soft-sediment benthos on small spatial scales on the order of $1 \mathrm{~m}$ (e.g. tidal elevation) and temporal scales of a few days. Previous transplantation experiments of individual bivalves, which grow more slowly than spionid polychaetes, have measured growth rates over several months (e.g. Peterson \& Black 1987, 1988, Matthews \& Fairweather 2003, 2008). These longer time periods are probably not sensitive to potentially important environmental variation that occurs on shorter time scales in many estuarine and coastal habitats, such as weather patterns, phytoplankton blooms, seasonal hypoxia, brief inputs of chemical pollutants, and recruitment pulses of competitors or predators. For example, Colvin \& Hentschel (2011) measured variation in the RGR of Polydora cornuta juveniles over a $14 \mathrm{mo}$ period at a single site and found that 4 major rain events (that significantly decreased salinity) reduced RGR to $0.00 \mathrm{~d}^{-1}$; worms transplanted just 1 to $2 \mathrm{wk}$ after major rain events always had RGRs $>0.08 \mathrm{~d}^{-1}$.

We caution that studies focused on effects of sediment geochemistry and biotic interactions on infaunal growth might need to modify some aspects of our methods. In particular, the sediment placed in our worm vials was standardized by sieving and by repeated freezing and thawing. The natural sediment and benthic community could be disrupted less by filling vials with sediment cores. Also, the vials and Plexiglas trays we used can inhibit porewater drainage, but we note that surface sediments in mudflats retain water and remain close to saturation throughout periods of tidal exposure due to 'capillary fringe' (Drabsch et al. 1999, Atherton et al. 2001, 
Kuwae et al. 2003). Furthermore, we have conducted a pilot study comparing RGRs of Polydora cornuta juveniles transplanted to intertidal sediment in vials with a Nitex mesh bottom $(0.2 \mathrm{~mm})$ and perforated trays to the impermeable vials and trays used in the present study and found no difference in RGR $(t=$ 1.689, $\mathrm{df}=7, \mathrm{p}=0.135$, authors' unpubl. data). Nevertheless, when research questions pertain directly to subsurface geochemistry, vials and trays that have fewer barriers to porewater exchange might be beneficial.

One of the intellectual challenges for ecologists is the extrapolation from mechanistic and tightly controlled laboratory experiments to field settings in which complex interactions among many environmental parameters and logistical constraints often prohibit direct, quantitative comparisons between the performance of organisms in the laboratory and in the field. The fastest RGRs we measured in situ are 3 to $4 \times$ less than the maximal RGRs of juvenile Polydora cornuta in laboratory flume experiments that used similar transplantation methods (Hentschel \& Larson 2005, 2006, Hentschel \& Herrick 2005). Those flume experiments with $P$. cornuta added phytoplankton that is probably a higher quality food than natural estuarine seston. In addition, slower growth at intertidal field sites is expected because worms in the flume experiments were able to suspension feed the entire time. However, constant submergence during the flume experiments (i.e. $\sim 3 \mathrm{~h}$ of additional submergence compared to what occurred at our lowintertidal elevation) explains only a small fraction of the difference between $P$. cornuta growth we measured in the field and previous laboratory flume experiments. Most of those flume experiments had simplified unidirectional currents with constant speeds. Times of slack tide and relatively slow currents between some of the intermediate low and high tides of mixed-semidiurnal tidal exchange probably also contributed to the slower RGRs we measured in the field. For example, Hentschel \& Herrick (2005) showed that laboratory flumes programmed to simulate semidiurnal tidal currents that varied in speed and direction led to RGRs of $\sim 0.3 \mathrm{~d}^{-1}$ compared to RGRs of $\sim 0.5 \mathrm{~d}^{-1}$ for small juvenile $P$. cornuta in laboratory flumes with constant, unidirectional current speeds (Hentschel \& Larson 2005). Conversely, very fast flows are known to decrease particle capture by spionids (Shimeta \& Jumars 1991, Shimeta \& Koehl 1997), and we have measured current speeds in Oneonta Slough faster than $45 \mathrm{~cm} \mathrm{~s}^{-1}$ during the peak ebb and flood tidal currents (authors' unpubl. data), which greatly exceed the $12 \mathrm{~cm} \mathrm{~s}^{-1}$ maximum speeds in laboratory flume experiments measuring $P$. cornuta RGRs $>0.3 \mathrm{~d}^{-1}$. We also suspect that, in nature, other organisms interfere with the feeding activities of $P$. cornuta juveniles and further reduce the time worms spend feeding in the field relative to laboratory experiments. For example, Hentschel \& Larson (2006) showed that the RGRs of juvenile $P$. cornuta are reduced in the presence of nearby adults that produce fecal mounds. In addition, sub-lethal predation on the feeding palps of spionids is well documented (e.g. Zajac 1995, Tomiyama et al. 2007), and the presence of predators probably causes worms to retract into the safety of their tubes, as occurs with mechanical stimulation in the laboratory (authors' pers. obs.). The transplantation methods we have developed provide a means to test these and other hypotheses concerning the growth and performance of infauna directly in situ to complement potentially problematic extrapolations from laboratory experiments.

Spionids are important and abundant members of soft-sediment communities (Noji \& Noji 1991, Cummings et al. 1996, Stehlik \& Meise 2000, Bolam \& Fernandes 2002, 2003). The early juvenile period has been suggested as a possible bottleneck in the dynamics of benthic populations (e.g. Jumars et al. 1990, Hentschel \& Jumars 1994, Olafsson et al. 1994, Gosselin \& Qian 1997, Hunt \& Scheibling 1997, Hentschel 1998a,b). Several studies modeling the population dynamics of spionids indicate that juvenile growth is a critical factor (Levin \& Huggett 1990, Zajac 1991a,b, Levin et al. 1996b). These models were partly based on the growth rates of juveniles from laboratory experiments in still water. Although in situ estimates of growth rates are not entirely free of potential artifacts, they should facilitate improved parameterization of models.

Acknowledgements. M. Colvin, Z. Scott, B. Peña, A. Mejia, V. Gray, M. Moore, A. Williamson and D. Hondolero assisted in the lab and field. The staff of the Tijuana River National Estuarine Research Reserve, especially J. Crooks and B. Collins, permitted access and helped facilitate our fieldwork. Comments by A.-M. Torregrossa, M. Colvin, K. Stocks, and 3 anonymous reviewers improved earlier versions of this manuscript. Funding was provided by National Oceanic and Atmospheric Administration (NOAA) Grant NA08OAR4170669, California Sea Grant Project R/CZ-199 through NOAA's National Sea Grant College Program, US Dept. of Commerce. Environmental monitoring data were collected and processed under an award to J. Crooks from the Estuarine Reserves Division, Office of Ocean and Coastal Resource Management, National Ocean Service, NOAA. This is Contribution No. 14 of the Coastal and Marine Institute Laboratory, San Diego State University. 


\section{LITERATURE CITED}

Atherton RJ, Baird AJ, Wiggs GFS (2001) Inter-tidal dynamics of surface moisture content on a meso-tidal beach. J Coast Res 17:482-489

Barnes H, Powell HT (1953) The growth of Balanus balanoides (L.) and B. crenatus Brug under varying conditions of submersion. J Mar Biol Assoc UK 32:107-127

Bishop MJ, Peterson CH (2006) Direct effects of physical stress can be counteracted by indirect benefits: oyster growth on a tidal elevation gradient. Oecologia 147: 426-433

Blake JA, Maciolek NJ (1987) A redescription of Polydora cornuta Bosc (Polychaeta: Spionidae) and designation of a neotype. Bull Biol Soc Wash 7:11-15

Bock MJ, Miller DC (1995) Storm effects on particulate food resources on an intertidal sandflat. J Exp Mar Biol Ecol 187:81-101

Bock MJ, Miller DC (1996) Fluid flow and suspended particulates as determinants of polychaete feeding behavior. J Mar Res 54:565-588

Bolam SG, Fernandes TF (2002) Dense aggregations of tube-building polychaetes: response to small-scale disturbances. J Exp Mar Biol Ecol 269:197-222

Bolam SG, Fernandes TF (2003) Dense aggregations of Pygospio elegans (Claparede): effect on macrofaunal community structure and sediments. J Sea Res 49:171-185

Colvin MA, Hentschel BT (2011) Seasonal variability in the juvenile growth rate of an infaunal polychaete is related to major rain events. Limnol Oceanogr 56:2095-2102

> Conlan KE, Kim SL, Thurber AR, Hendrycks E (2010) Benthic changes at McMurdo Station, Antarctica following local sewage treatment and regional iceberg-mediated productivity decline. Mar Pollut Bull 60:419-432

Connell JH (1972) Community interactions on marine rocky intertidal shores. Annu Rev Ecol Syst 3:169-192

> Cummings VJ, Pridmore RD, Thrush SF, Hewitt HE (1996) Effect of the spionid polychaete Boccardia syrtis on the distribution and survival of juvenile Macomona liliana (Bivalvia: Tellinacea). Mar Biol 126:91-98

> Dauer DM, Maybury CA, Ewing RM (1981) Feeding-behavior and general ecology of several spionid polychaetes from the Chesapeake Bay. J Exp Mar Biol Ecol 54:21-38

Dittmann S (2000) Zonation of benthic communities in a tropical tidal flat of north-east Australia. J Sea Res 43: 33-51

> Drabsch JM, Parnell KE, Hume TM, Dolphin TJ (1999) The capillary fringe and the water table in an intertidal estuarine sand flat. Estuar Coast Shelf Sci 48:215-222

Fisher RA (1921) Some remarks on the methods formulated in a recent article on 'The quanitative analysis of plant growth.' . Ann Appl Biol 7:367-372

> Gaines S, Roughgarden J (1985) Larval settlement rate: a leading determinant of structure in an ecological community of the marine intertidal zone. Proc Natl Acad Sci USA 82:3707-3711

Gosselin LA, Qian PY (1997) Juvenile mortality in benthic marine invertebrates. Mar Ecol Prog Ser 146:265-282

Griffiths RJ, Buffenstein R (1981) Aerial exposure and energy input in the bivalve Choromytilus meridionalis (Kr.). J Exp Mar Biol Ecol 52:219-229

Hentschel BT (1998a) Intraspecific variations in $\delta^{13} \mathrm{C}$ indicate ontogenetic diet changes in deposit-feeding polychaetes. Ecology 79:1357-1370

Hentschel BT (1998b) Spectrofluorometric quantification of neutral and polar lipids suggests a food-related recruitment bottleneck for juveniles of a deposit-feeding polychaete population. Limnol Oceanogr 43:543-549

Hentschel BT (2004) Sediment resuspension and boundary layer flow dramatically increase the growth rates of interface-feeding spionid polychaetes. J Mar Syst 49: 209-224

- Hentschel BT, Herrick BS (2005) Growth rates of interfacefeeding spionid polychaetes in simulated tidal currents. J Mar Res 63:983-999

Hentschel BT, Jumars PA (1994) In situ chemical inhibition of benthic diatom growth affects recruitment of competing, permanent and temporary meiofauna. Limnol Oceanogr 39:816-838

- Hentschel BT, Larson AA (2005) Growth rates of interfacefeeding polychaetes: combined effects of flow speed and suspended food concentration. Mar Ecol Prog Ser 293: 119-129

Hentschel BT, Larson AA (2006) Hydrodynamic mediation of density-dependent growth and adult-juvenile interactions of a spionid polychaete. Limnol Oceanogr 51: 1031-1037

> Hunt HL, Scheibling RE (1997) Role of early post-settlement mortality in recruitment of benthic marine invertebrates. Mar Ecol Prog Ser 155:269-301

Jarrett JN (2003) Seasonal variation in larval condition and post-settlement performance of the barnacle Semibalanus balanoides. Ecology 84:384-390

Jumars PA, Mayer LM, Deming JW, Baross JA, Wheatcroft RA (1990) Deep-sea deposit feeding strategies suggested by environmental and feeding constraints. Philos Trans R Soc Lond A 331:85-101

Kneib RT (1984) Patterns of invertebrate distribution and abundance in the intertidal salt-marsh: causes and questions. Estuaries 7:392-412

> Kuwae T, Kibe E, Nakamura Y (2003) Effect of emersion and immersion on the pore water nutrient dynamics of an intertidal sandflat in Tokyo bay. Estuar Coast Shelf Sci 57:929-940

> Larson AA, Stachowicz JJ, Hentschel BT (2009) The effect of a tube-building phoronid on associated infaunal species diversity, composition and community structure. J Exp Mar Biol Ecol 381:126-135

Levin LA, Huggett DV (1990) Implications of alternative reproductive modes for seasonality and demography in an estuarine polychaete. Ecology 71:2191-2208

Levin LA, Talley D, Thayer G (1996a) Succession of macrobenthos in a created salt marsh. Mar Ecol Prog Ser 141: $67-82$

Levin L, Caswell H, Bridges T, Dibacco C, Cabrera D, Plaia G (1996b) Demographic responses of estuarine polychaetes to pollutants: life table response experiments. Ecol Appl 6:1295-1313

Marsh AG, Tenore KR (1990) The role of nutrition in regulating the population dynamics of opportunistic surface deposit feeders in a mesohaline community. Limnol Oceanogr 35:710-724

> Matthews TG, Fairweather PG (2003) Growth rates of the infaunal bivalve Soletellina alba (Lamarck, 1818) (Bivalvia: Psammobiidae) in an intermittent estuary of southern Australia. Estuar Coast Shelf Sci 58:873-885

Matthews TG, Fairweather PG (2008) In situ growth of Soletellina alba (Bivalvia: Psammobiidae) in response to detrital supply and mouth status in a seasonally-closed estuary. Estuar Coast Shelf Sci 78:145-154 
Menge BA, Sutherland JP (1976) Species-diversity gradients: synthesis of roles of predation, competition, and temporal heterogeneity. Am Nat 110:351-369

Miller DC, Jumars PA (1986) Pellet accumulation, sediment supply, and crowding as determinants of surface depositfeeding rate in Pseudopolydora kempi japonica Imajima and Hartman (Polychaeta: Spionidae). J Exp Mar Biol Ecol 99:1-17

Miller DC, Jumars PA, Nowell ARM (1984) Effects of sediment transport on deposit feeding: scaling arguments. Limnol Oceanogr 29:1202-1217

National Oceanic and Atmospheric Administration (NOAA) (2004) Office of Ocean and Coastal Resource Management, National Estuarine Research Reserve System-wide Monitoring Program, Centralized Data Management Office, Baruch Marine Field Lab, University of South Carolina, available at http://cdmo.baruch.sc.edu

Noji CIM, Noji TT (1991) Tube lawns of spionid polychaetes and their significance for recolonization of disturbed benthic substrates. Meeresforschung 33:235-246

Olafsson EB, Peterson CH, Ambrose WG (1994) Does recruitment limitation structure populations and communities of macro-invertebrates in marine soft sediments: the relative significance of pre- and post-settlement processes. Oceanogr Mar Biol Annu Rev 32:65-109

Pearson TH, Rosenberg R (1978) Macrobenthic succession in relation to organic enrichment and pollution of the marine environment. Oceanogr Mar Biol Ann Rev 16: 229-311

Peterson $\mathrm{CH}$ (1991) Intertidal zonation of marine-invertebrates in sand and mud. Am Sci 79:236-249

> Peterson CH, Black R (1987) Resource depletion by active suspension feeders on tidal flats: influence of local density and tidal elevation. Limnol Oceanogr 32:143-166

Peterson CH, Black R (1988) Responses of growth to elevation fail to explain vertical zonation of suspensionfeeding bivalves on a tidal flat. Oecologia 76:423-429

> Peterson CH, Black R (1991) Preliminary evidence for progressive sestonic food depletion in incoming tide over a broad tidal sand flat. Estuar Coast Shelf Sci 32:405-413

Phillips NE (2004) Variable timing of larval food has consequences for early juvenile performance in a marine mussel. Ecology 85:2341-2346

Qian PY, Chia FS (1994) In situ measurement of recruitment, mortality, growth, and fecundity of Capitella sp. (Annelida: Polychaeta). Mar Ecol Prog Ser 111:53-62

Seed R (1969) Ecology of Mytilus edulis L. (Lamellibranchiata) on exposed rocky shores. II. Growth and mortality. Oecologia 3:317-350

Shimeta J, Jumars PA (1991) Physical mechanisms and rates of particle capture by suspension feeders. Oceanogr Mar Biol 29:191-257

Shimeta J, Koehl MAR (1997) Mechanisms of particle selection by tentaculate suspension feeders during encounter, retention, and handling. J Exp Mar Biol Ecol

Editorial responsibility: Pei-Yuan Qian,

Kowloon, Hong Kong SAR, China
209:47-73

Stehlik LL, Meise CJ (2000) Diet of winter flounder in a New Jersey estuary: ontogenetic change and spatial variation. Estuaries 23:381-391

- Stocks KI (2002) Flume experiments on post-settlement movement in polychaetes. J Mar Res 60:743-762

Suchanek TH (1978) The ecology of Mytilus edulis L. in exposed rocky intertidal communities. J Exp Mar Biol Ecol 31:105-120

> Taghon GL, Greene RR (1992) Utilization of deposited and suspended particulate matter by benthic interface feeders. Limnol Oceanogr 37:1370-1391

Taghon GL, Nowell ARM, Jumars PA (1980) Induction of suspension feeding in spionid polychaetes by high particulate fluxes. Science 210:562-564

Thompson ML, Schaffner LC (2001) Population biology and secondary production of the suspension feeding polychaete Chaetopterus $c f$. variopedatus: implications for benthic-pelagic coupling in lower Chesapeake Bay. Limnol Oceanogr 46:1899-1907

Thrush SF, Whitlatch RB, Pridmore RD, Hewitt JE, Cummings VJ, Wilkinson MR (1996) Scale-dependent recolonization: the role of sediment stability in a dynamic sandflat habitat. Ecology 77:2472-2487

- Tomiyama T, Omori M, Minami T (2007) Feeding and growth of juvenile stone flounder in estuaries: generality and the importance of sub-lethal tissue cropping of benthic invertebrates. Mar Biol 151:365-376

Underwood AJ (1985) Physical factors and biological interactions: the necessity and nature of ecological experiments. In: Moore PG, Seed R (eds) The ecology of rocky coasts. Hodder and Stoughton, London, p 372-390

> van Erkom Schurink C, Griffiths CL (1993) Factors affecting relative rates of growth in four South African mussel species. Aquaculture 109:257-273

Wethey DS (1984) Sun and shade mediate competition in the barnacles Chthamalus and Semibalanus: a field experiment. Biol Bull 167:176-185

Wilson WH Jr (1983) The role of density dependence in a marine infaunal community. Ecology 64:295-306

Woodin SA (2007) Behavioral cues, recruitment, and relative mobility: rocky shores vs. sediments. Bull Mar Sci 81: 181-189

Zajac RN (1991a) Population ecology of Polydora ligni (Polychaeta: Spionidae). I. Seasonal variation in population characteristics and reproductive activity. Mar Ecol Prog Ser 77:197-206

Z Zajac RN (1991b) Population ecology of Polydora ligni (Polychaeta: Spionidae). II. Seasonal demographic variation and its potential impact on life-history evolution. Mar Ecol Prog Ser 77:207-220

- Zajac RN (1995) Sub-lethal predation on Polydora cornuta (Polychaeta: Spionidae): patterns of tissue loss in a field population, predator functional response and potential demographic impacts. Mar Biol 123:531-541

Submitted: February 17, 2011; Accepted: August 4, 2011 Proofs received from author(s): November 28, 2011 